\title{
Characterization of Leptospires according to Fatty Acid Requirements
}

\author{
By R. C. JOHNSON, VIRGINIA G. HARRIS \\ AND JUDITH K. WALBY \\ Department of Microbiology, University of Minnesota, \\ Minneapolis, Minnesota 55455, U.S.A.
}

(Accepted for publication 6 November 1968)

\begin{abstract}
SUMMARY
The fatty acid requirements of leptospires parasitic for mammals were compared to those of members of the 'biflexa complex' (leptospires not clearly demonstrated to be animal parasites). The parasitic leptospires grew on unsaturated fatty acids. Saturated fatty acids were not utilized unless an unsaturated fatty acid was also provided. This requirement for an unsaturated fatty acid was increased at temperatures above and below the optimal. In addition, these leptospires did not utilize fatty acids containing less than I 5 to 16 carbon atoms unless a longer chain fatty acid was also present. Leptospires of the 'biflexa complex' had neither of these requirements. These leptospires grew on either long or short chain, saturated or unsaturated fatty acids. Utilizing these differences in fatty acid requirements, a means of differentiating these two groups of leptospires is provided. Members of the 'biflexa complex' but not the parasitic leptospires grew on an albumin medium containing $5 \times 10^{-4} \mathrm{M}$-myristic acid, the 14 -carbon saturated fatty acid.
\end{abstract}

\section{INTRODUCTION}

The genus Leptospira is at present represented by a single species, $L$. interrogans (World Health Organization, 1967). However, there appears to be two major 'complexes' of leptospires within the genus: The 'parasitic complex' which contains leptospires parasitic for man and animals, and the 'biflexa complex' which contains the so-called 'water' leptospires and other leptospires not clearly demonstrated to be parasitic for animals. Fatty acids are the major carbon and energy source for leptospires of both complexes. Recently, Auran \& Johnson (I968) reported that long chain alcohols would also serve as a major carbon and energy source. In addition, they reported that serotype pomona Wickard, a member of the 'parasitic complex', required an unsaturated fatty acid for growth, whereas serotype patoc Patoc I, a member of the 'biflexa complex', did not. This report is concerned with the fatty acid requirements of the leptospires as related to fatty acid chain length, presence or absence of double bonds and effect of incubation temperature. A method of differentiating the two complexes based on fatty acid requirements is also described. 


\section{METHODS}

\section{Media and cultural procedures}

The source of the leptospires used in this study was described by Johnson \& Harris (I968). The nomenclature used for the leptospiral cultures used in this report is that recommended by a WHO Expert Group (World Health Organization, 1967). The cultures were maintained in a Tween $80+$ albumin medium, a modification of that described by Ellinghausen \& McCullough (1965), which was prepared as described by Johnson \& Harris (1967). Incubation was at $30^{\circ}$ in the dark.

The albumin medium used in the nutritional studies was prepared as follows: Separate stock solutions were made in distilled water $\left(\mathrm{g} . / 100 \mathrm{ml}\right.$.) of $\mathrm{NH}_{4} \mathrm{Cl}, 25$; $\mathrm{ZnSO}_{4} \cdot 7 \mathrm{H}_{2} \mathrm{O}, 0 \cdot 4 ; \mathrm{CaCl}_{2} \cdot 2 \mathrm{H}_{2} \mathrm{O}$ and $\mathrm{MgCl}_{2} \cdot 6 \mathrm{H}_{2} \mathrm{O}$, I g. each; $\mathrm{FeSO}_{4} \cdot 7 \mathrm{H}_{2} \mathrm{O}, 0.5$; $\mathrm{CuSO}_{4} \cdot 5 \mathrm{H}_{2} \mathrm{O}, 0.3$; glycerol, 10 ; thiamine $\mathrm{HCl}, 0.5$; and vitamin $\mathrm{B}_{12}, 0.02$. The $\mathrm{pH}$ of the stock solutions was not adjusted. The basal medium consisted of $\mathrm{Na}_{2} \mathrm{HPO}_{4}$ (I g.), $\mathrm{KH}_{2} \mathrm{PO}_{4}\left(0 \cdot 3 \mathrm{~g}\right.$.), $\mathrm{NaCl}$ (I g.) and $\mathrm{NH}_{4} \mathrm{Cl}$, thiamine and glycerol stocks (I ml. each) in $997 \mathrm{ml}$. of distilled water, adjusted to $\mathrm{pH} \mathrm{7.4}$; sterilized at $121^{\circ}$ for $20 \mathrm{~min}$.

The albumin supplement was prepared by adding $20 \mathrm{~g}$. of fatty acid-poor bovine albumin, Fraction V (Pentex, Inc., Kankakee, Ill.) to $100 \mathrm{ml}$. distilled water. The following stock solutions (in $\mathrm{ml}$.) were added slowly to the albumin solution while it was being stirred: calcium and magnesium chloride, 2; zinc sulfate, 2; copper sulphate, 0.2 ; iron sulfate, 20 ; and vitamin $\mathrm{B}_{12}, 2.0$. The $\mathrm{pH}$ of the albumin solution was adjusted to $7 \cdot 4$ and the final volume to $200 \mathrm{ml}$. The albumin supplement was sterilized by filtration. The test medium was prepared by adding $\mathrm{I}$ vol. albumin supplement to 9 vol. basal medium.

Tweens (Atlas Chemical Industries, Wilmington, Del.) were added to the basal medium and sterilized by autoclaving. The fatty acids (Hormel Institute, Austin, Minn.) were of high purity ( $99 \%$ ). The unsaturated fatty acids were sterilized at $12 \mathrm{I}^{\circ}$ for $20 \mathrm{~min}$. in sealed vials under $\mathrm{N}_{2}$. The sodium salts of the unsaturated acids were prepared with sterile $\mathrm{NaOH}$ and the fatty acid salt was added aseptically to the sterile test medium. The saturated fatty acids were dissolved in ethanol, to which $\mathrm{NaOH}$ was added, and added to the basal medium. Autoclaving removed the ethanol. One vol. albumin supplement was added to 9 vol. basal medium containing the saturated fatty acid.

Organisms used for the nutritional studies were from cultures in the logarithmic or early stationary phase of growth. Unless stated otherwise, a $1 \%(v / v)$ inoculum, which yielded approximately $3 \times 10^{6}$ organism per $\mathrm{ml}$. in the test medium, was used. Growth was measured daily with a Coleman (model 7) photonephelometer calibrated with an arbitrary standard (Roessler \& Brewer, 1967). The relationship between nephelometer reading and number of organisms was verified by periodic counts with a Petroff-Hausser counting chamber.

\section{RESULTS}

Growth of leptospires on fatty acid esters at several temperatures

Preliminary experiments indicated that the ability of leptospires to grow on fatty acids varied with the fatty acid ester, incubation temperature and leptospiral serotype. Three serotypes of leptospires were selected which manifested different growth 
patterns on a fatty acid-poor albumin medium containing polyoxyethylene sorbitan monolaurate (Tween 20), monopalmitate (Tween 40), monostearate (Tween 60) or monooleate (Tween 80). One of the serotypes selected, serotype semaranga, is a member of the 'biflexa complex'. This serotype grew on all the Tweens at $13^{\circ}, 30^{\circ}$ and $34^{\circ}$ and to approximately the same extent on each Tween at a given temperature (Table I). Serotypes canicola and ballum, members of the 'parasitic complex', did not grow on any of the Tweens at $13^{\circ}$. As the incubation temperature was increased to $17^{\circ}$, some growth of serotype canicola occurred in Tween 20 and good growth in Tween 80. However, no growth occurred in Tween 40 and 60 . At $30^{\circ}$ and $34^{\circ}$ growth of this serotype was observed on all the Tweens (Table I). Serotype ballum differed from serotype canicola in that Tween 80 was the only Tween that supported growth at $17^{\circ}, 30^{\circ}$ and $34^{\circ}$. Hence, at a near minimal growth temperature, the unsaturated fatty acid ester was the best substrate for serotype canicola and it was the only fatty acid ester which supported the growth of serotype ballum at $17^{\circ}, 30^{\circ}$ or $34^{\circ}$. Moreover, a difference in fatty acid requirement between members of the 'biflexa complex' and 'parasitic complex' is apparent.

Table I. Growth of leptospires on various Tweens at different temperatures*

$\begin{array}{cccccc}\text { Serotype tested } & \begin{array}{c}\text { Incubation } \\ \text { temperature }\end{array} & \begin{array}{c}\text { Tween 20 } \\ \left(\mathbf{C}_{18}\right) \dagger\end{array} & \begin{array}{c}\text { Tween } 40 \\ \left(\mathbf{C}_{18}\right) \dagger\end{array} & \begin{array}{c}\text { Tween } 60 \\ \left(\mathbf{C}_{18}\right) \dagger\end{array} & \begin{array}{c}\text { Tween } 80 \\ \left(\mathbf{C}_{18: 1}\right) \dagger\end{array} \\ \text { semaranga } & 13^{\circ} & 42 & 43 & 35 & 46 \\ \text { VELDRAT SEMARANGA } & 30^{\circ} & 42 & 52 & 45 & 50 \\ \text { I73 } & 34^{\circ} & 30 & 24 & 30 & 28 \\ \text { canicola } & 13^{\circ} & <2 & <2 & <2 & <2 \\ \text { HOND UTRECHT IV } & 17^{\circ} & 23 & <2 & <2 & 52 \\ & 30^{\circ} & 48 & 44 & 37 & 52 \\ \text { ballum SIO2 } & 34^{\circ} & 34 & 28 & 27 & 31 \\ & 13^{\circ} & <2 & <2 & <2 & <2 \\ & 17^{\circ} & <2 & <2 & <2 & <2 \\ & 30^{\circ} & <2 & <2 & <2 & 44 \\ & 34^{\circ} & <2 & <2 & <2 & 30\end{array}$

* Tween concentration $0.1 \%(v / v)$. Incubation time at $30^{\circ}$ and $34^{\circ}$ was 5-7 days, and at $13^{\circ}$ and $17^{\circ}$ it was $10-14$ days.

$\dagger$ Major fatty acid component of Tween.

\section{Growth of leptospires on fatty acids}

Since the Tweens are not chemical entities but rather are mixtures of fatty acid esters with one member of the mixture being the major component, we tested media in which the Tweens were replaced by high purity fatty acids. Serotype semaranga grew on all the saturated and unsaturated fatty acids tested (Table 2). The growth pattern of serotype canicola and ballum on these fatty acids differed markedly from that of serotype semaranga. The parasitic serotypes only grew well on the long chain unsaturated fatty acids, palmitoleic $\left(\mathrm{C}_{16: 1}\right)$ and oleic $\left(\mathrm{C}_{18: 1}\right)$. Poor or no growth occurred on the shorter chain unsaturated fatty acid, myristoleic $\left(C_{14: 1}\right)$, and on the saturated fatty acids, lauric $\left(C_{12}\right)$, myristic $\left(C_{14}\right)$, palmitic $\left(C_{18}\right)$ and stearic $\left(C_{18}\right)$ (Table 2).

To determine whether the saturated fatty acids were growth inhibitory per se or were substrates which the members of the 'parasitic complex' could not utilize, the 
growth of leptospires in the albumin medium containing $\mathrm{I} \times \mathrm{IO}^{-4} \mathrm{M}$ of the unsaturated fatty acid, oleic acid, and $3 \times 10^{-4} \mathrm{M}$ of a saturated fatty acid was investigated. Serotype semaranga grew well on the saturated fatty acids in presence or absence of oleic acid. In contrast to serotype semaranga, the growth of serotypes canicola and ballum on saturated fatty acids was markedly affected by the presence of oleic acid. In the absence of oleic acid, no significant growth occurred on $3 \times 10^{-4} \mathrm{M}$-palmitic acid. However, good growth occurred on this fatty acid in the presence of oleic acid (Table 3). The amount of growth obtained was several times that with oleic acid alone, which demonstrated that the saturated fatty acid was utilized. Similar results were obtained

Table 2. Growth of leptospires on various fatty acids*

\begin{tabular}{|c|c|c|c|c|c|c|c|}
\hline \multirow[b]{2}{*}{ Serotype tested } & \multicolumn{7}{|c|}{ Fatty acid tested $\left(3 \times 10^{-4} \mathrm{M}\right)$} \\
\hline & $\begin{array}{c}\text { Lauric } \\
\left(\mathrm{C}_{12}\right)\end{array}$ & $\begin{array}{c}\text { Myristic } \\
\left(C_{14}\right)\end{array}$ & $\begin{array}{c}\text { Palmitic } \\
\left(\mathrm{C}_{16}\right)\end{array}$ & $\begin{array}{c}\text { Stearic } \\
\left(\mathrm{C}_{18}\right)\end{array}$ & $\begin{array}{c}\text { Myristoleic } \\
\left(\mathrm{C}_{14: 1}\right)\end{array}$ & $\begin{array}{l}\text { Palmitoleic } \\
\left(\mathrm{C}_{18: 1}\right)\end{array}$ & $\begin{array}{c}\text { Oleic } \\
\left(\mathbf{C}_{\mathbf{1 8 . 1}}\right)\end{array}$ \\
\hline $\begin{array}{l}\text { semaranga } \\
\text { VELDRAT SEMARANGA } \\
\text { I73 }\end{array}$ & 43 & 38 & $5 I$ & 48 & 35 & 55 & 53 \\
\hline $\begin{array}{l}\text { canicola } \\
\text { HOND UTRECHT IV }\end{array}$ & 15 & $<2$ & $<2$ & $<2$ & 4 & 45 & $5 \mathrm{I}$ \\
\hline $\begin{array}{l}\text { ballum } \\
\text { S } 102\end{array}$ & $<2$ & $<2$ & $<2$ & $<2$ & $<2$ & 36 & $4 I$ \\
\hline
\end{tabular}

* Growth expressed as number of leptospires $\times 10^{7} / \mathrm{ml}$. Incubation was at $30^{\circ}$ for 7 -10 days. The first number in parentheses under the common name of the fatty acid indicates number of carbon atoms; the second number indicates the number of unsaturated bonds. Similar results were obtained with 2 and $4 \times 10^{-4} \mathrm{M}$ concentrations of these fatty acids.

Table 3. Effect of an unsaturated fatty acid on the growth of leptospires on a saturated fatty acid*

\begin{tabular}{lccc} 
& \multicolumn{3}{c}{ Fatty acids tested } \\
$\begin{array}{l}\text { Oleic }\left(\mathrm{C}_{18: 1}\right) \\
\mathrm{I} \times 10^{-4} \mathrm{M}\end{array}$ & $\begin{array}{c}\text { Palmitic }\left(\mathrm{C}_{16}\right) \\
3 \times 10^{-4} \mathrm{M}\end{array}$ & $\begin{array}{c}\text { Palmitic } 3 \times 10^{-4} \mathrm{M} \\
\text { +oleic } 1 \times 10^{-4} \mathrm{M}\end{array}$ \\
$\begin{array}{l}\text { semaranga } \\
\text { VELDRAT SEMARANGA } 173\end{array}$ & 28 & 53 & 66 \\
$\begin{array}{l}\text { canicola } \\
\text { HOND UTRECHT IV } \\
\text { ballum }\end{array}$ & 27 & $<2$ & 68 \\
S I02 & 19 & $<2$ & 57
\end{tabular}

* Growth expressed as number of leptospires $\times 10^{7} / \mathrm{ml}$. Incubation was at $30^{\circ}$ for 7 to 10 days.

with the saturated fatty acids, lauric, myristic and stearic. This data indicated that the parasitic leptospires were unable to utilize the saturated fatty acids unless an unsaturated fatty acid was present. Serotype semaranga, a member of the 'biflexa complex', did not manifest this requirement for an unsaturated fatty acid.

Various unsaturated fatty acids were tested for their capacity to permit serotype ballum to utilize the saturated fatty acids. A concentration of $\mathrm{I} \times 1 \mathrm{IO}^{-4} \mathrm{M}$-linolenic $\left(C_{18: 3}\right)$, linoleic $\left(C_{18: 2}\right)$, oleic (cis-9-I 8:I), palmitoleic or myristoleic acid permitted serotype ballum to grow on $3 \times 10^{-4} \mathrm{M}$-palmitic acid. Thus, the polyunsaturated fatty 
acids as well as unsaturated fatty acids varying in chain length from I 8 to 14 carbon atoms were capable of permitting growth on palmitic acid. However, chain length became a factor when the unsaturated fatty acid was the sole carbon and energy source.

\section{Effect of fatty acid chain length on leptospiral growth}

Myristoleic acid was not a satisfactory carbon and energy source for serotypes ballum or canicola, whereas unsaturated fatty acids containing greater than 14 carbon atoms were suitable growth substrates (Table 2). These observations suggested that the parasitic leptospires required both an unsaturated fatty acid and a chain length of greater than 14 carbon atoms for growth. Serotypes ballum and canicola were therefore inoculated into media containing $3 \times 10^{-4} \mathrm{M}$-myristoleic and $\mathrm{I} \times 1 \mathrm{IO}^{-4}$ M-lauric, tridecanoic $\left(\mathrm{C}_{13}\right)$, myristic, pentadecanoic $\left(\mathrm{C}_{15}\right)$, palmitic, or heptadecanoic $\left(\mathrm{C}_{17}\right)$ acid. As seen in Table 4, growth of serotype canicola occurred in myristoleic acid only when the supplemental fatty acid contained 15 or more carbon atoms. Serotype ballum required a supplemental fatty acid of at least 16 carbon atoms.

Table 4. Effect of fatty acid chain length on growth of leptospires on myristoleic acid*

\begin{tabular}{|c|c|c|c|}
\hline \multirow[b]{2}{*}{$\begin{array}{l}\text { Additions to test medium } \\
\text { containing } \\
3 \times 10^{-4} \mathrm{M} \text {-myristoleic acid } \\
\left(\mathrm{C}_{14: 1}\right) \dagger\end{array}$} & \multicolumn{3}{|c|}{ Serotypes tested } \\
\hline & $\begin{array}{c}\text { semaranga } \\
\text { VELDRAT } \\
\text { SEMARANGA } 173\end{array}$ & $\begin{array}{l}\text { canicola } \\
\text { HOND } \\
\text { UTRECHT IV }\end{array}$ & ballum s 102 \\
\hline None & 34 & 3 & $<2$ \\
\hline Lauric acid $\left(\mathrm{C}_{12}\right)$ & 40 & $<2$ & $<2$ \\
\hline Tridecanoic acid $\left(\mathrm{C}_{18}\right)$ & 38 & $<2$ & $<2$ \\
\hline Myristic acid $\left(\mathrm{C}_{14}\right)$ & $4 I$ & $<2$ & $<2$ \\
\hline Pentadecanoic acid $\left(\mathrm{C}_{15}\right)$ & 46 & $43 \ddagger$ & $<2$ \\
\hline Palmitic acid $\left(\mathrm{C}_{16}\right)$ & 55 & 48 & 38 \\
\hline Heptadecanoic acid $\left(\mathbf{C}_{17}\right)$ & 58 & 54 & 46 \\
\hline
\end{tabular}

\section{Effect of temperature on fatty acid requirement}

The experiment with the Tweens (Table I) indicated that the parasitic leptospires had an increased requirement for an unsaturated fatty acid at $17^{\circ}$. The effect of temperature on the fatty acid requirement of serotype canicola was investigated. As seen in Table 5, ratios of oleic acid to myristic acid of greater than $\mathrm{r}: 4$ would not support growth of serotype canicola at $17^{\circ}$, whereas at $30^{\circ}$, growth occurred in the $r: 32$ ratio. At $36^{\circ}$, an increase in the oleic acid requirement was also observed. Growth occurred in the $I: 2$ ratio but not the $I: 4$ ratio.

The growth of the parasitic serotypes on the Tweens also suggested that serotype ballum had a greater requirement for unsaturated fatty acids than serotype canicola (Table I). The growth of these two serotypes on varying ratios of oleic and myristic acid at different temperatures was compared (Table 5). Serotype ballum was restricted to growth in media containing only oleic acid at $17^{\circ}$ and $36^{\circ}$, whereas serotype canicola grew at these temperatures in ratios of $I: 4$ and $I: 2$ respectively. At $30^{\circ}$ serotype canicola grew in a ratio of $\mathrm{I}: 32$ of these fatty acids, while serotype ballum was restricted to ratios of $\mathrm{I}: 2$ or less. Several other parasitic serotypes also were found to differ in 
their requirement for unsaturated fatty acids. Serotypes tarassovi, alexi, poi, coxi and celledoni required higher proportions of oleic acid to grow on myristic acid than did serotypes wolffi, grippotyphosa and butembo. Thus, the first group of serotypes resemble serotype ballum and the latter, serotype canicola.

Table 5. Effect of temperature on the fatty acid requirements

\begin{tabular}{|c|c|c|c|c|c|c|c|c|}
\hline \multirow{2}{*}{$\begin{array}{c}\text { Temperature } \\
\text { of } \\
\text { incubation }\end{array}$} & \multicolumn{8}{|c|}{ Ratio of oleic acid $\left(C_{18: 1}\right)$ to myristic acid $\left(C_{14}\right)$} \\
\hline & $6: 0$ & $\mathbf{I}: \mathbf{I}$ & $1: 2$ & $I: 4$ & $\mathrm{I}: 8$ & $I: 16$ & I:32 & $0: 6$ \\
\hline & \multicolumn{8}{|c|}{ Serotype canicola HOND UTRECHT IV } \\
\hline $\begin{array}{l}17^{\circ} \\
30^{\circ} \\
36^{\circ}\end{array}$ & $\begin{array}{l}56 \\
38 \\
38\end{array}$ & $\begin{array}{l}70 \\
70 \\
33\end{array}$ & $\begin{array}{l}57 \\
74 \\
21\end{array}$ & $\begin{array}{r}31 \\
72 \\
<2\end{array}$ & $\begin{array}{r}<2 \\
76 \\
<2\end{array}$ & $\begin{array}{r}<2 \\
53 \\
<2\end{array}$ & $\begin{array}{r}<2 \\
34 \\
<2\end{array}$ & $\begin{array}{l}<2 \\
<2 \\
<2\end{array}$ \\
\hline \multicolumn{9}{|c|}{ Serotype ballum $\mathrm{s} 102$} \\
\hline $17^{\circ}$ & 32 & $<2$ & $<2$ & $<2$ & $<2$ & $<2$ & $<2$ & $<2$ \\
\hline $30^{\circ}$ & 38 & 33 & 30 & $<2$ & $<2$ & $<2$ & $<2$ & $<2$ \\
\hline $36^{\circ}$ & 37 & $<2$ & $<2$ & $<2$ & $<2$ & $<2$ & $<2$ & $<2$ \\
\hline
\end{tabular}

Inoculum size, $5 \%(\mathrm{v} / \mathrm{v})$. Incubation times: $17^{\circ}, 18$ days; $30^{\circ}$ and $36^{\circ}, 7$ days. Total fatty acid concentration, $6 \times 10^{-4} \mathrm{M}$. Growth expressed as number of leptospires $\times 10^{7}$ per $\mathrm{ml}$.

Table 6. Growth of 'biflexa complex' leptospires on $5 \times 10^{-4}$ M-myristic acid $\left(C_{14}\right)$

$\begin{array}{lc}\begin{array}{l}\text { Serogroup } \\ \text { Serotype, strain }\end{array} & \begin{array}{c}\text { Number of leptospires } \\ \times 10^{7} \text { per ml. }\end{array} \\ \begin{array}{l}\text { Semaranga } \\ \text { semaranga, VELDRAT SEMARANGA } 173\end{array} & 48 \\ \text { patoc PATOC I } & 63 \\ \text { sao-paulo SAO PAULO } & 49 \\ \text { Andamana } & \\ \text { andamana CH I } & 30 \\ \text { andamana CORREO } & 46 \\ \text { Biflexa } & \\ \text { biflexa A-284 } & 38 \\ \text { biflexa CDC } & 33 \\ \text { biflexa LT 430 } & 68 \\ \text { biflexa LT965 } & 43 \\ \text { biflexa } \text { WAZ } & 43 \\ \text { biflexa GENT } & 18\end{array}$

Incubation was at $30^{\circ}$ for 7 -10 days.

The parasitic leptospires, serotypes ballum and canicola, did not grow in myristic acid (Table 2) unless the medium was supplemented with an unsaturated fatty acid such as oleic acid. Serotype semaranga, a member of the 'biflexa complex', grew well in myristic acid in the absence of any exogenous source of unsaturated fatty acid (Table 2). These observations suggested that this difference in the requirement for an unsaturated fatty acid might serve as a taxonomic tool for differentiating leptospires of the 'parasitic complex' from those of the 'biflexa complex'. To test this possibility, media containing $5 \times 1^{-4} \mathrm{M}$-myristic acid was tested for its ability to support the growth of 24 serotypes of the 'parasitic complex' and II members of the 'biflexa complex'. A I \% (v/v) was found to be most satisfactory for this study. Serotypes alexi HS616, arboreae ARBOREA, australis BALLICO, bakeri LT79, ballum MUS127, 
bataviae SWART, borincana HS622, butembo BUTEMBO, canicola HOND UTRECHT IV, castellonis CASTELLON 3, celledoni CELLEDONI, copenhageni M20, coxi coX, gatuni LT 839, grippotyphosa MAL I540, icterohaemorrhagiae W39, javanica VELDRAT BATAVIAE 46, kabura KABURA, mankarso MANKARSO, pomona POMONA, pyrogenes SALINEM, rachmati RACHMAT, sarmin SARMIN, sorex-jalna SOREX-JALNA and wolffii 3705, members of the 'parasitic complex', were unable to grow in $5 \times 10^{-4} \mathrm{M}$-myristic acid. As seen in Table 6, all leptospires of the 'biflexa complex' grew in this medium.

\section{DISCUSSION}

We recently reported that leptospires of the 'biflexa complex' could be differentiated from those of the 'parasitic complex' by their ability to grow at low temperatures (Johnson \& Harris, 1967). The minimal growth temperature of the parasitic leptospires was between $13^{\circ}$ and $15^{\circ}$. Leptospires of the 'biflexa complex' have a minimal growth temperature between $5^{\circ}$ and $10^{\circ}$, or approximately $5^{\circ}$ below that of the pathogens. Preliminary studies indicated that differences in fatty acid requirements might be responsible in part for this difference in minimal growth temperature. As reported by Auran \& Johnson (1968) and in this paper, major differences in fatty acid requirement do exist between members of the two complexes of leptospires, and temperature does influence the fatty acid requirements of the parasitic leptospires. The parasitic leptospires cannot utilize saturated fatty acids unless they are also given an unsaturated fatty acid. Moreover, the parasitic leptospires cannot utilize either saturated or unsaturated fatty acids containing fewer than 15 to 16 carbon atoms as their sole carbon source. However, a longer chain fatty acid permits these leptospires to utilize the shorter chain fatty acids. Leptospires of the 'biflexa complex' have neither the requirement for fatty acid chain length nor the requirement for unsaturated fatty acids. They grow on saturated fatty acids containing less than $\mathrm{I} 5$ carbon atoms, although the longer chain fatty acids are better carbon and energy sources. The growth of leptospires of the 'biflexa complex' on the Tweens at temperatures above or below their optimal did not demonstrate any temperature-relative change in their fatty acid requirements. In contrast, the parasitic leptospires, when growing on mixtures of saturated and unsaturated fatty acids, required increased proportions of unsaturated fatty acids at near minimal and maximal growth temperatures. The basis for this unsaturated fatty acid requirement of the parasitic leptospires is not known at the present time.

The fatty acid requirements of parasitic leptospires have been studied in media containing serum or serum fractions and in synthetic media. Oleic acid or compounds containing this unsaturated fatty acid supported good growth of leptospires in media containing extracted rabbit serum (Van Eseltine \& Staples, 196I), extracted rabbit serum albumin (Johnson \& Gary, I963), and bovine albumin (Ellinghausen \& McCullough, 1965). The inability of parasitic leptospires to utilize saturated fatty acids was not observed in our earlier work (Johnson \& Gary, 1963). We reported that serotype pomona grew in an extracted albumin medium with either long or short chain saturated fatty acids as the major added carbon source. The most probable explanation for the discrepant results is that sufficient long chain unsaturated fatty acid remained in the albumin preparation to allow growth on the saturated fatty acids. Both saturated and unsaturated fatty acids have been reported to serve as the carbon 
source for parasitic leptospires grown in synthetic media (Vogel \& Hutner, I96I; Stalheim \& Wilson, 1964; Van Eseltine, Adams, Prochazka \& Wooley, 1967; Shenberg, 1967). It is difficult to evaluate the results of these studies since: (I) many of the strains of leptospires used were selected for their ability to grow in the media (e.g. nutritional mutants); (2) fatty acid-binding agents such as albumin were missing from these media making it difficult to differentiate between the nutritional qualities of the fatty acids and their lytic activities. In general, synthetic media containing oleate esters supported the best growth. It is of interest to note that the serotypes of parasitic leptospires that grew poorly or not at all in the synthetic medium of Shenberg (1967) are those which we found to have a high requirement for unsaturated fatty acids.

The usual habitat of the parasitic leptospires is the mammal. In this controlled environment the leptospires are exposed to a constant temperature and an abundant source of long chain saturated and unsaturated fatty acids. The leptospires of the 'biflexa complex' have not been clearly demonstrated to be animal parasites and appear to be closely associated with a soil-water environment in nature (Henry \& Johnson, I968). In this environment they are exposed to variations in available nutrients as well as variations in temperature. Because the leptospires of this group must be more adaptable, they have the enzymes necessary for utilizing either saturated or unsaturated fatty acids, the shorter chain fatty acids, and an enzymic make-up which allows them to grow in a wide range of temperatures below their optimal. In contrast, the parasitic leptospires depend upon the types of fatty acids available in the mammalian host, namely the long chain saturated and unsaturated fatty acids, and they do not grow well at the low temperatures. Serotypes such as ballum, which are lipase (trioleinase) negative (Johnson \& Harris, 1968), having a relatively high requirement for unsaturated fatty acids and not producing a severe disease in mammals, are probably older, well-adapted parasites. Serotypes such as canicola, which possess lipase activity, having a lesser requirement for unsaturated fatty acids and producing a more severe disease, may be parasites of more recent origin.

This work was supported by Public Health Service grant AI-06589 from the National Institute of Allergy and Infectious Diseases.

\section{REFERENCES}

Auran, T. B. \& Johnson, R. C. (1968). Nutrition and growth of leptospires. Bact. Proc. p. 27. Ellinghausen, H. C., Jun. \& MCCullough, W. G. (1965). Nutrition of Leptospira pomona and growth of 13 other serotypes: Fractionation of oleic albumin complex and a medium of bovine albumin and polysorbate. Am. J. vet. Res. 26, 45.

HeNRY, R. A. \& Johnson, R. C. (1968). Ecological studies on leptospires of the 'biflexa complex'. Bact. Proc. 1968, p. 33.

Johnson, R. C. \& GARY, N. C. (1963). Nutrition of Leptospira pomona. II. Fatty acid requirements. J. Bact. $85,976$.

Johnson, R. C. \& HARris, V. G. (1967). Differentiation of pathogenic and saprophytic leptospires. I. Growth at low temperatures. J. Bact. 94, 27.

Johnson, R. C. \& HarRis, V. G. (I968). Purine analogue and lipase activity of leptospires. Appl. Microbiol. 16, 1584 .

Roessler, W. G. \& BREWER, C. R. (1967). Permanent turbidity standards. Appl. Microbiol. r5, III. 
SHENBERG, E. (1967). Growth of pathogenic Leptospira in chemically defined media. J. Bact. 93, I598. Stalheim, O. H. V. \& Wilson, J. B. (1964). Cultivation of leptospirae. II. Growth and lysis in synthetic medium. J. Bact. 88, 55.

van Eseltine, W. P. \& Staples, S. A. (1961). Nutritional requirements of leptospirae. I. Studies on oleic acid as a growth factor for a strain of Leptospira pomona. J. infect. Dis. 108, 262.

van Eseltine, W. P., Adams, M. A., Prochazka, J. K. \& Wooley, R. E. (1967). Nutritional requirements of leptospirae. II. A chemically defined medium supporting growth of Leptospira pomona. Bull. Georgia Acad. Sci. $25,222$.

VoGeL, H. \& HutNer, S. H. (I96I). Growth of Leptospira in defined media. J. gen. Microbiol. 26, 223.

WORLD HEALTH ORGANIZATION. (1967). Current problems in leptospirosis research. Wld Hlth Org. techn. Rep. Ser. 380. 